\title{
EFFECT OF INTRAVENTRICULAR INJECTIONS OF $\omega$-AMINOSULFONIC ACIDS ON THE CENTRAL NERVOUS SYSTEM OF CONSCIOUS MICE
}

\author{
Kazuyoshi HORISAKA and Kazuko WATANABE \\ Department of Pharmacology, Kobe Women's College of Pharmacy, \\ Kobe 658, Japan
}

Accepted June 1, 1979

In the course of a survey on the physiological role of taurine (2-aminoethanesulfonic acid, $\mathrm{C}_{2}$ ) and related compounds, we focused attention on the relationships between chemical structures and pharmacological effects. In earlier studies we found that intravenous administration of homotaurine (3-aminopropanesulfonic acid, $\mathrm{C}_{3}$ ) produced a marked decrease in blood pressure in dogs. Both taurine and $\mathrm{N}$-methyl- or side chain-derivatives of $\mathrm{C}_{3}$ had a weaker effect than $C_{3}(1)$. These results were much the same as those obtained by Stanton and Woodhouse (2), lino (3), Tsujioka et al. (4) and Takahashi et al. (5) with $r$-aminobutyric acid (GABA) derivatives, the carboxylic analogues of $\mathrm{C}_{3}$.

Behavior patterns in conscious mice given aliphatic ()-aminosulfonic acids which had a carbon chain from one to six (Fig. 1), were pursued to determine if there was any evident correlation between behavior and chemical structures of the acids.

Male ddY mice, weighing $20 \pm 1 \mathrm{~g}$ were separated into groups. Each group included 10 mice. Each amino acid was dissolved in physiological saline, neutralized with sodium hydroxide solution and the solution $(5, / 1)$ administered directly into the cerebral lateral ventricle, according to the method of Haley and McCormick (6), with slight modifications (7).

All amino acids tested induced a similar type of dosage dependent convulsion, that is, immediately or within 1 min after injection, an extreme running convulsion was evoked, and tonic flexor to tonic extensor convulsions occurred before death. When the tonic flexor convulsion resulted in clonic convulsion, the animals survived.

$$
\begin{aligned}
& \mathrm{H}_{2} \mathrm{~N}^{-\mathrm{CH}_{2}-\mathrm{CH}_{2}-\mathrm{CH}_{2}-\mathrm{CH}_{2}-\mathrm{CH}_{2}-\mathrm{SO}_{3} \mathrm{H}} \begin{array}{l}
\text { 5-aminopentanesulfonic acid } \\
\left(\mathrm{C}_{5}\right)
\end{array}
\end{aligned}
$$

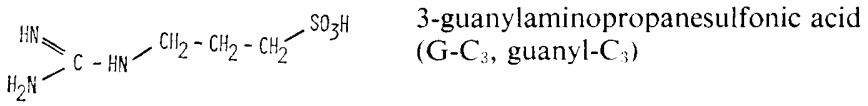

$$
\begin{aligned}
& \mathrm{H}_{2} \mathrm{~N}-\mathrm{CH}_{2}-\mathrm{CH}_{2}-\mathrm{CH}_{2}^{-} \mathrm{SO}_{3} \mathrm{H} \quad \begin{array}{l}
\text { 3-aminopropanesulfonic acid } \\
\left(\mathrm{C}_{3}\right)
\end{array} \\
& \mathrm{H}_{2} \mathrm{~N}-\mathrm{CH}_{2}-\mathrm{CH}-\mathrm{CH}_{2}-\mathrm{SO}_{3} \mathrm{H} \quad \begin{array}{l}
\text { 3-amino-2-hydroxypropanesulfonic acid } \\
\text { (AHPS) }
\end{array}
\end{aligned}
$$

FIG. 1 (1)-Aminosulfonic acids and its guanylated derivative. 
The dose-response curves of amino acids tested are shown in Fig. 2. Shifting of a curve to the left indicates that the tested material produced an enhanced convulsion. We classified such amino acids as excitants. As seen from Fig. 2, these were 4-aminobutanesulfonic acid $\left(C_{4}\right)$, 5-aminopentanesulfonic acid $\left(C_{5}\right)$, 6-aminohexanesulfonic acid $\left(C_{6}\right)$, guanyl- $C_{3}\left(G-C_{3}\right)$, 3-guanylamino-2-hydroxypropanesulfonic acid (G-AHPS) and homocysteic acid (HCA).

On the other hand, aminomethanesulfonic acid $\left(\mathrm{C}_{1}\right)$, 3-mono-methylamino-2-hydroxypropanesulfonic acid (Me-AHPS) and 3-trimethylamino-2-hydroxypropanesulfonic acid (AHPS-betaine) written on the right side bottom in Fig. 2 had no effect on the behavior of mice even at the most elevated concentration of $2 \times 10^{-1} \mathrm{M}$. Such were classified as inactive amino acids.

The materials of a third type had an effect even with a moderate concentration, which included $\mathrm{C}_{2}, \mathrm{C}_{3}$ and 3-amino-2-hydroxypropanesulfonic acid (AHPS). When injected, these substances at the concentration of $2-6 \times 10^{-2} \mathrm{M}$, mice produced biphasic behavioral patterns, that is a temporary excitatory tendency induced by external stimuli such as touch and the sedation leading to drowsiness. Such were also observed with administration of

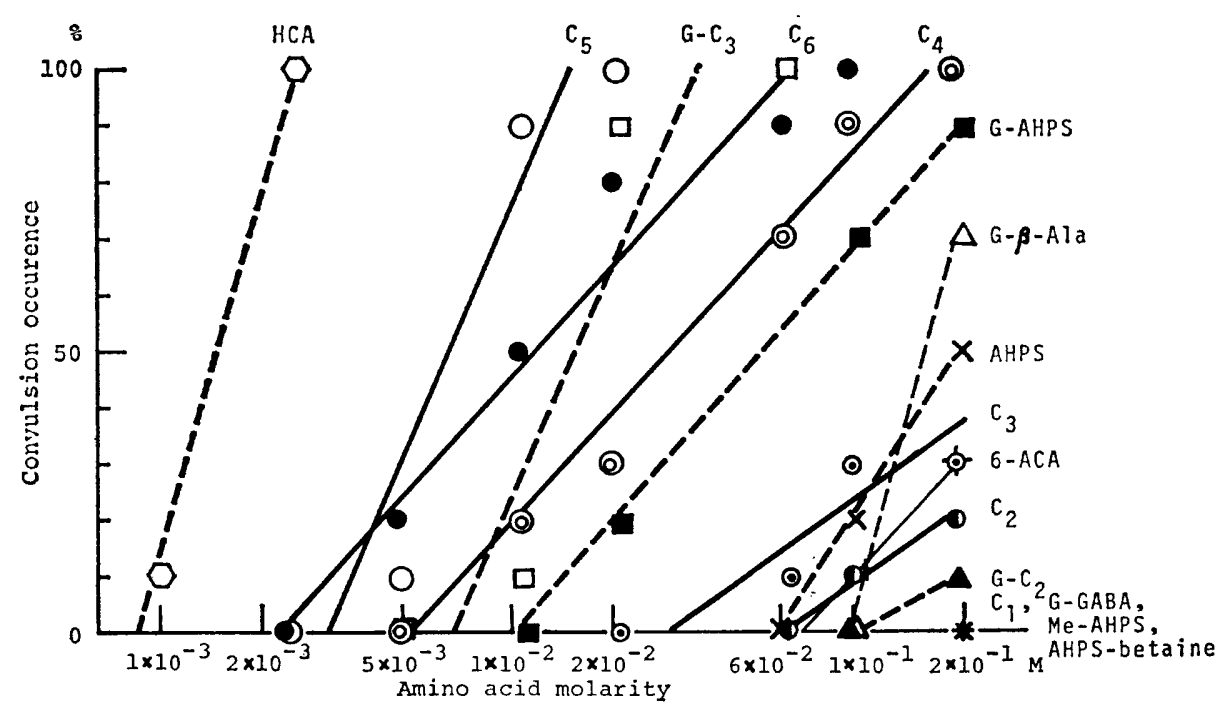

FIG. 2. Dose-response curves for action of $\omega$-aminosulfonic acids and related compounds upon CNS of mice.

$\bigcirc \cdot--\square$ HCA: DL-homocysteic acid

$\bigcirc \mathrm{C}_{5}: 5$-aminopentanesulfonic acid

$\square \cdot--\square$ G-C $\mathrm{C}_{3}:$ 3-guanylaminopropanesulfonic acid

$\mathrm{C}_{6}:$ 6-aminohexanesulfonic acid

(2)-(-) $\mathrm{C}_{4}$ : 4-aminobutanesulfonic acid

․--D G-AHPS: 3-guanylamino-2-hydroxypropane sulfonic acid

$\triangle \cdots \triangle$ G- $\beta$-Ala: guanyl- $\beta$-alanine

$\times \cdot-\cdots \times$ AHPS: 3-amino-2-hydroxypropanesulfonic acid $\odot-\odot \mathrm{C}_{3}:$ 3-aminopropanesulfonic acid

+-+6 -ACA: 6-aminocaproic acid

O- $\mathrm{C}_{2}$ : taurine

$\Delta---\Delta$ G- $C_{2}$ : taurocyamine

* $\mathrm{C}_{1}$ : aminomethanesulfonic acid

* G-GABA: $\gamma$-guanidinobutyric acid

* Me-AHPS: 3-monomethylamino-

2-hydroxypropanesulfonic acid

* AHPS-betaine: 3-trimethylamino-

2-hydroxypropanesulfonic acid 
GABA to mice, as reported by Gulati and Stanton (8). We classified these amino acids as depressants.

From the above experimental results we speculated that it may be necessary to have a four to six aliphatic carbon chain between the anionic and cationic sites for demonstration of the excitement. A basic character of $\omega$-amino group seems to be required for production of the convulsive activities, since methylation of $\omega$-amino group of AHPS (N-monomethyl and N,N,N-trimethyl derivatives) reduced and guanylation of AHPS or $\mathrm{C}_{3}$ enhanced the convulsive activities, in comparison with those of the parent compounds, respectively. The acidity constant may be related to the convulsive activities since $\omega$-aminosulfonic acids were much more potent excitants than $\omega$-aminocarboxylic acids such as 6-aminocaproic acid (6-ACA).

\section{REFERENCES}

1) Tsunoo, Sh., Horisaka, K., Tanabe, H., Chida, T., Nakajima, S. and Fukai, Z.: Pharmacological studies of aminosulfonic acids. 1. Hypotensive effect of $\omega$-aminosulfonic acids. Showa Igakkai Zasshi 30, 521-531 (1970) (Abs. in German)

2) Stanton, H.C. and Woodhouse, F.H.: The effect of gamma-amino-n-butyric acid and some related compounds on the cardiovascular system of anesthetized dogs. J. Pharmacol. exp. Ther. 128, 233-242 (1960)

3) IINo, M.: Effects of $\gamma$-amino butyric acid and its related amino acids on blood pressure and respiration. Nippon Seirigaku Zasshi 17, 766-773 (1955) (Abs. in English)

4) TsuJioka, T., Fukuya, M. AND TsuchiYa, K.: Effects of $\omega$-amino acids on the blood pressure. Nippon Seirigaku Zasshi 22, 63-69 (1960) (Abs. in English)

5) Takahashi, H., Koshino, Ch. AND IKeda, O.: Relationship between the hypotensive activity and chemical structure of $\gamma$-aminobutyric acid in the rabbit. Japan. J. Physiol. 12, 97-105 (1962)

6) Haley, T.J. and McCormick, W.G.: Pharmacological effects produced by intracerebral injection of drugs in the conscious mouse. Brit. J. Pharmacol. 12, 12-15 (1957)

7) NaKajima, S.: Convulsions induced by vitamin $\mathbf{B}_{6}$ antagonists and their prevention. Showa Igakkai Zasshi 32, 193-202 (1972) (Abs. in English)

8) Gulati, O.D. and Stanton, H.C.: Some effects on the central nervous system of gammaamino-n-butyric acid (GABA) and certain related amino acids administered systemically and intracerebrally to mice. J. Pharmacol. exp. Ther. 129, 178-185 (1960) 